\title{
INDIA AND BUSINESS PROCESS OUTSOURCING
}

Thite, M. \& Russell, R. (2007). India \& Business Process Outsourcing. In Burgess, J \&

Connell, J. (Eds.) Globalisation \& Work in Asia. Oxford: Chandos Publishing

\section{Introduction}

Employment and work relations in India are as complex as Indian society itself, which, more than ever, is characterized by extreme forms of uneven development. In this chapter we largely focus on one sector of the economy, which is heavily implicated in the current phase of globalisation - referred to as the IT/ITeS/BPO sector. This acronym stands for information technology, information technology enabled services and business process outsourcing industries. At the moment, it is investment in this sector which is powering the Indian economy and which has drawn attention from around the world. It is sometimes said in India that the country largely missed out on the opportunities and benefits of the industrial revolution. However, the IT revolution is seen as means of redressing this situation in the context of a developing knowledge economy. It is certainly the case that up until the recent parliamentary elections of 2004, governments dedicated much of their policy emphasis towards attracting both foreign and domestic IT/ITeS/BPO investment. In short, knowledge and information based industries have very quickly attained a place of prominence in the Indian economy and are centrally implicated with the processes of globalisation that are so hotly contested. For these reasons, the bulk of the chapter concentrates on analysing emergent employment relations in the IT/ITeS/BPO sector.

This chapter is based upon a month of field work which the authors carried out jointly in India in 2005 as well as earlier field work conducted by Thite. In preparation for this work the authors designed two open-ended, qualitative interview protocols, one for the operations manager(s) and another for the human resources manager(s) at each organisational case study site. Four of India's large BPO providers participated in the study. The average number of employees in these firms was 5500 and their call centres were spread across all the major cities in India. Detailed information was sought in these interviews on topics such as employee costs, business profiles, recruitment and labour market challenges, relationships with clients, and work design. Interviews were conducted at each company's headquarters. In total eight managerial interviews were conducted, although in a number of cases, these included sessions with part or all of the whole managerial team in charge of operations or HR. Observer triangulation was practiced in each case. That is, both authors took notes, entered them into computer files and then exchanged the files with each other in order to add additional material that might have been missed.

This primary data is supplemented by other material that is referred to in the chapter. Company, industry (such as National Association of Software and Service Companies NASSCOM) and consultant reports were accessed while in India. National and state level Government documents pertaining to industrial relations statutes in general, and to the IT/ITES/BPO sector specifically were collected. As were local Shops and Establishment Acts and Rules, which establish local employment conditions. Other material that was used includes census data and Bureau of Labour data, that were collected during the field trip to India. 
Unfortunately, it was not possible to engage in direct field observation during this project. Each of the four Indian companies included in the study were strictly outsourcing providers to overseas (mainly American) clients. Concerns over principle/provider confidentiality, especially in the wake of damaging international press stories concerning data privacy, proved to be too large a hurdle to overcome. Each of the companies did, however, agree to administer an employee survey that the authors had designed as a counterpart to the management interviews. Results from this work are referred to only en passant in this chapter, which is intended to provide an overview of Indian employment relations in the context of globalisation.

Before focusing on the Indian outsourcing phenomena, a general overview of the Indian economy is provided in the next section. This is then followed by three sections that examine: the growth and current state of the IT/ITeS/BPO sector in the Indian economy; labour and employment relations in this sector; and the challenges and contradictions that are emerging from the unique mix of a knowledge intensive industry set in the context of marginal social conditions. A short concluding section draws the main themes and issues of the chapter together.

\section{The Indian Economy in the New Millennium}

With a land mass less than 25 percent larger than the state of Western Australia, and an economy that is ranked as the twelfth largest in the world, India passed the one billion population mark early in the new millennium and is predicted to become the most populous country on the planet within the next 20 years. It is necessary to keep in mind that the overwhelming majority of this population, around three-quarters, remains on the land or lives outside of the major cities. Just under 60 percent (58.2 percent) of the country's labour force is to be found in agricultural production, listed either as cultivators (31.7 percent), or agricultural labourers (26.5 percent). Another four percent of the total workforce is included within the category of household industry, while just over one-third of the labour force, (37.6 percent), lumped together in the residual 'other' category, which would include both manufacturing industry and service provision (Census of India, 2001). Women are overrepresented in the agrarian labour category (39 percent of all recorded female workers, compared with 21 percent of male workers) and have less than half the representation in the industry and service categories (21.7 percent) that are recorded by men.

Official data also makes the distinction between the organised sector of the economy and the unorganised. The former refers to public and private enterprises, which pay wages and salaries, are covered by federal and state laws and maintain annual accounts. This sector accounts for approximately 10 percent of the total labour force, with the remainder falling outside of the official sector in small, informal undertakings that are often characterised by underemployment and casualisation. Within the organised sector community, social and personal service labour constitutes the largest element -42 percent of all workers in this category. This includes workers in both the expanding private sector and public sector employment (Director General of Employment and Training, various years). Workers in manufacturing employment account for 24.7 percent of the total, transportation another 11.3 percent, while employees in finance, insurance, real estate and associated business services compose 6 percent of total employment in this sphere. The bulk of IT/ITeS/BPO employment is located in this latter category. 
All up, the combined IT/ITeS/BPO sector employs under 1 million workers out of a total workforce (waged, salaried and other) that is approaching half a billion workers! It is difficult to fathom a large new middle class being thrown up by these developments, and indeed it is still the case that 35\% of all Indians live on less than \$1 US per day (Economist, March 5, 2005). Rather, we suggest that the importance of this sector is to be found elsewhere, specifically in the changes wrought to trade patterns, as they affect India as an exporter and her new found trading partners. In 1995, the top five exports (by value and in order of importance) from India were gems and jewellery, garments, textiles, marine products and leather ware (not including footwear). Ten years later the list reads as follows: software; engineering goods; gems and jewellery; chemicals and related products; and textiles. Software design chalked up \$US 17.2 billion in exports in 2005, compared with 13.7 billion for gems/jewellery (Gupta and Kumarkaushalam, 2005). India's largest export market and overall trading partner is the US, which accounted for $20 \%$ of exports, many in the IT/ITeS field, followed by China (8.3\%), UAE (8\%) and UK (5\%) (Economist, 2006). Even though India's share of global trade remains at under 1 percent, ( $\$ 250$ billion US in 2004), it is these shifting trade patterns that have become synonymous with globalisation and, in the process, have attracted considerable attention in both India and overseas (Sheshabalaya, 2005; Kripalani and Engardio, 2005). Notably, IT/ITeS/BPO activity has been associated with surpassing what had become known in the 1970-80s as the 'Hindu rate of growth'. This refers to economic growth rates, which although positive, lagged behind population growth. In the first years of the new millennium (2001-2005) real economic growth ran at 6.5\%, still well behind China's, but against population growth of 1.5\% per annum (Economist, 2005).

\section{The Indian IT/ITES/BPO Sector}

Off-shoring, as part of global business realignment, is considered the third wave in global expansion by companies, after global export and global production. IT services include systems integration and information systems consulting, application development and support as well as IT training services. IT-enabled Services (ITeS) cover a wide range of services, depending on the nature of expertise, from:

- back-office data entry and processing, to

- customer contact services (such as complaints, tele-marketing, collections support), to

- corporate support functions (such as HR, finance, procurement, IT services), to

- knowledge services and decision-support (such as customer analytics, claims and risk management and consultancy), and to

- research and development services (such as engineering design, content development and new product design). (KPMG, 2004).

The global IT/ITeS market was estimated to be worth US\$1,322 billion in 2003 and is expected to grow to US\$3,391 billion by 2012 at a compounded annual growth of $11 \%$, while the size of the ITeS market will continue to be around twice that of the IT services market (Taskforce, 2003). India is quickly emerging as "the services-hub of the world" with a $24 \%$ share of the off-shored IT/ITeS market in 2002; however, India's share of the global IT/ITeS market was still low at $0.8 \%$ in 2002. (KPMG, 2004). The Indian IT/ITeS sector is expected to earn a revenue of US\$28 billion in 2004-05 (Nasscom-a, 2005). This is expected to grow to $\$ 148$ billion by 2012, accounting for about $4.4 \%$ of the global market (Taskforce, 2003).

India's bid for off-shore IT/ITeS business is driven by a number of factors. Most notably there is the availability of an appropriately skilled human resource base that is estimated to 
include 14 million tertiary educated graduates. Moreover, by international standards, even highly skilled labour remains cheap. Salary levels although escalating (see below) still range between one-tenth and one-fifth of that of equivalent jobs in the US. Finally, and more controversially, according to some, the ability to generate better quality work, more efficiently (with improved service levels of 5-10\% across different parameters such as customer satisfaction, response time, accuracy and speed) (KPMG, 2004) is a feature of outsourcing. However, it needs to be noted that it is difficult to measure efficiency levels at the macro level in the absence of hard, empirical data. In particular, it is necessary to distinguish between more productive work and more intense work. With regard to the latter topic, it remains the case that the legal work week in India is still 8 to 12 hours longer per week (48 hours) than is the norm in Western economies.

The spectacular growth of the Indian software industry, which first took India global, in the early 1990s has been mostly export led. The industry started its journey in the USA with the on-site model, where it cheaply rented out Indian software programmers to work at client sites under client supervision in the US. Thanks to factors such as Y2K projects and a shortage of IT personnel in the USA, the on-site model worked so well that, by the close of the1990s, Indians accounted for nearly half of the H-1B work permits, which are employersponsored non-immigrant visas for temporary workers, issued by the US Department of Immigration for IT-related occupations (Mittal and Goel, 2004).

Over the years, Indian software companies built a reputation for supplying large numbers of cheap, but high quality IT personnel, pushing IT companies in the USA to continue to lobby the US government to relax work permit regulations. With Euro conversion projects coming on stream in the late 1990s, European companies followed the US example in hiring Indian IT personnel, pushing up their demand as well as the profit margins of the Indian companies that employed them. As the confidence in the service delivery capability of Indian companies increased, part of the outsourced work (mainly coding) was shifted to India. In this way the off-shore model of export led informationalism gathered steam.

By early 2000, the Indian software industry had firmly established its capability and credibility as a strategic IT business partner using both on-shore and off-shore models. With the crash of the dot.com bubble, overseas companies started cutting their IT budgets and in the process, put pressure for increased efficiency at reduced cost on both their internal IT departments as well as outsourcing providers. This coincided with multinational firms' revaluation of their business processes, including back-office support functions, customer contact and care and corporate support functions through such initiatives as business process re-engineering. That is when business process outsourcing (BPO) came into being.

To most Indian software companies, BPO was an accidental opportunity and in many cases was initiated by their overseas clients. They had to quickly set up subsidiaries to exploit this new found opportunity which came in handy in the face of the downturn in the IT industry. Another stroke of luck for the industry was the cheap availability of abundant and underutilised fibre optic cables laid under the sea by western companies during the e-commerce hype generated in the 1990s and their increasing bandwidth capacity (Friedman, 2005). While the Indian software industry took more than 10 years to mature and climb up the value chain, the Indian ITeS/BPO industry has taken just 5 years (between 2000 and 2005) to do just that. Many of the top Indian software companies, namely, Infosys, Wipro and Satyam, have now set up subsidiary companies such as Progeon, Wipro BPO, and Nipuana, which are their ITES arms. 
According to NASSCOM, the premier trade body and the chamber of commerce of the IT software and services industry in India, the Indian IT/ITeS industry earned an estimated USD 28.2 billion in 2004-05, of which IT services and software accounted for 58.6\%, the ITeSBPO, 20\% and hardware 21\% (Nasscom-b, 2005). Today, there are around 3000 IT companies in India currently exporting to over 150 countries with an employee base of around 700,000. The top 5 Indian IT software \& service exporters are Tata Consultancy Services, Infosys, Wipro, Satyam and HCL (Nasscom-c, 2005).

There are over $400 \mathrm{ITeS} / \mathrm{BPO}$ companies in India that include a mix of captive units (wholly dedicated set ups of both Multi National Companies and Indian companies accounting for $65 \%$ of the market) and third-party services providers with a total employee base of around 350,000 (Nasscom-d, 2005). In 2004-05, the ITeS-BPO segment witnessed a growth of $45 \%$ to reach USD 5.2 billion that constituted $30 \%$ of the total IT-ITeS exports from India. The top 5 third-party (call centre \& BPO) players are WNS Global Services, Wipro BPO, HCL Technologies BPO, IBM-Daksh and ICICI OneSource. Reflecting complementary strengths between IT and ITeS, the integration of IT-BPO contracts is becoming more common. Nasscom also reports that "the ITES-BPO companies are gaining significant traction in transaction processing; with more and more firms balancing voice and non-voice business portfolios to diversify revenue and raise seat utilisation” (Nasscom-e, 2005).

The Indian ITeS/BPO industry is maturing very quickly. Today it includes, high-end business services, such as knowledge services and decision-support (that is customer analytics, claims, risk management and consultancy) and research and development services (eg. engineering design, content development and new product design). These high-end services are part of what is now called Knowledge Process Outsourcing (KPO) and they are expected to provide over 40\% of total Indian BPO revenues in 2010 (The Hindu, 2005a). In line with this growth, the ITeS/BPO/KPO industry now employs not only generic graduates as Customer Service Representatives (CSRs) but also MBAs, doctors, engineers and chartered accountants as process executives. Even at the CSR level, the data collected by the authors in four Indian companies suggests that more than $85 \%$ of employees are university graduates. This compares with a figure of about $20 \%$ of their counterparts in Australia (see Russell's study of 20 Australian customer contact centres) XX. Another interesting point of comparison is to be found in the age demographics of the industry. Over $90 \%$ of employees in the Indian ITeS/BPO industry are under 30 years of age (DQ-IDC, 2004). In our survey at the four Indian BPO centres, 92\% of the respondents $(\mathrm{N}=638)$ were under the age of 30 . This compares with $40 \%$ of Russell's Australian call centre sample $(\mathrm{N}=1232)$ that were under 30 years of age.

The IT/ITeS sector has inserted itself at various levels of the value chain from low level, low value services (such as code-writing and call centres) to complex and more profitable functions such as data management, market analysis, consulting, and computer-aided design (Chandler, 2005). However, this has not been a linear development progressing from low end to high value activities over time. Rather, it is better stylised as a set of ad hoc opportunities that began with IT, and then moved down the ladder into ITeS. It is now entering into KPO with the outsourcing of medical diagnostic, legal, financial and other forms of professional work from western economies. The growth of Indian IT/ITeS firms has been stellar, occurring via mergers and acquisitions, through the expansion of operations overseas (investments by Indian BPOs in such countries as the Philippines, China, Czechoslovakia and Australia), and through strategic alliances with multinational companies. This form of 
globalisation has entailed obtaining internationally recognised quality accreditation certificates, adopting world-class HR best practices, and benchmarking with leading firms from across the globe (ibid). Quality certification is a hallmark of the Indian IT/ITeS sector. For example, $90 \%$ of ITeS/BPO companies have a dedicated quality department with $50 \%$ having implemented various levels of ISO and 45\% having Six Sigma and other certifications (Nasscom-f, 2005).

Leveraging on human capital to overcome deficiencies in physical capital figures largely in these processes and lies at the heart of current economic developments (Mittal and Goel, 2004). To date, this represents a unique, if untested, strategy for overcoming decades of lagging performance. The absence of adequate infrastructure in India poses real problems for development. For example, the nation's patchy highway network includes just 124,000 miles of road compared to China's 870,000 (Chandler, 2005). Urban congestion on the roads and in the skies is notorious. Rather than denigrating the importance of physical infrastructure, many 'new economy' theorists (Reich, 1991; Florida, 2002) stress the importance of not only physical infrastructure but also cultural amenities as a key to successful transition/prosperity in the knowledge economy. Whether infrastructural inadequacies prove to be an insurmountable obstacle to development, or whether the new economy of export led service provision has peculiarities that render such infrastructure less important remains to be seen.

Meanwhile, many western firms are now looking at different ways of leveraging both domestic and offshore markets. In the US, "leading-edge providers are upskilling US-based agents to take on revenue generating as well as customer retention activities and offshoring the support and service enquiries” (Datamonitor, 2005: 65). In Australia, the ANZ bank is similarly increasing its operations roles in Bangalore and, at the same time, creating new jobs and opportunities in customer facing areas in Australia (Jones, 2005). The implications of this are considered later in this chapter.

\section{Employment Regulation}

This section examines the relevance of the Indian industrial relations system, specifically the existing political/legal framework to the IT/ITES/BPO industries. Unsurprisingly, we come to the conclusion that the national regulatory regime and the global BPO industry mainly exist in different 'worlds'. IT/ITES/BPO is largely regulated by the interaction of global capital flows and local labour market dynamics while existing forms of regulation have been marginalised. We begin by describing what those forms of regulation are. Next, we describe the current HR-Employment Relations scene in the ITES/BPO sector. These dynamics have important implications for both workers and other organisations in the IR system, such as trade unions. The implications of this are also analysed.

Employment relations in India are regulated by a number of legal instruments, commencing with the Trade Union Act of 1926. This Act, initially provided for the registration of trade unions and, in the process, provided specific immunities from conspiracies in restraint of trade and civil actions for breach of contract (Krishnamurthi, 2002). The legislation still specifies a minimum membership of only seven workers for registration. This, in turn, has given rise to a huge number of registered unions (64,817 in 1999), with a very small average base (786 members) (India Labour Bureau, 2004).

The Trade Union legislation was silent on the question of union recognition by employers and this remained the case until 1958, when the Standing Labour Committee of the Federal 
Government devised protocols for representation and collective bargaining rights that were agreed to by representatives of industry and labour. These were appended to the Voluntary Code of Discipline, wherein management agreed to recognise the union which had the largest membership constituency for any given establishment or industry. This could be determined by either an examination conducted by the Ministry of Labour of the financial records/membership of the contending unions or, where all parties, including the employer agree, by way of a secret ballot conducted by the Ministry. To trigger recognition, the actual union membership threshold is quite low - minimally 2 percent of the workforce in question. In exchange for this, unions agreed to subscribe to a code of discipline of their own. This includes such provisions as no strikes without notification, a renunciation of coercion, work to rule tactics and sit-down strikes and a willingness to discipline officials and members who act in disregard of the code, (Krishnamurthi, 2002, ch.6).

With respect to all of these undertakings it is important to keep two essential points in the foreground. First, these protocols represented a voluntary undertaking on the part of business and labour leaders. They may or may not be respected in any specific case. Union recognition is not a statutory requirement of Indian employment relations law. As one commentator reminds us, such "codes are virtually buried for all practical purposes and have become part of industrial relations history” (Ratnam, 2001, p.42). In part, inter-union rivalry, (see below) has militated against finding agreement on principles for union recognition. Secondly, under the 1926 Act, union membership also remains voluntary. There are no legal provisions for closed or union shop rules, or for the automatic check-off of membership dues.

Union recognition is also referred to in the 1947 Industrial Disputes Act. This omnibus bill was designed to foster orderly industrial relations on the sub-continent (Sodhi and Plowman, 2001). Appended to the bill (Schedule Five) is a lengthy list of unfair labour practices, which includes proscriptions against interference in union organising, including discrimination against union members, the use of threats or coercion, including threats to shut down operations, the creation of company or company dominated unions, or the refusal to bargain in good faith with the recognised union. Employers are also forbidden from recruiting replacement workers during legal strikes or employing casual or temporary workers on a long term basis, although penalties for transgressions of such rules seem to be minimal.

The 1947 Act also establishes rules for the settlement of disputes involving wages, working hours, occupational classifications, layoffs, retrenchments and technological change. Depending upon the issue, a Labour Court may be established to deal with cases of dismissals, the legality of strikes/lockouts, or the withdrawal of existing conditions while an Industrial Tribunal may be created to process disputes over compensation, hours of work, job classification, technological change or reductions in employment. Awards are made by the Labour Courts, Industrial Tribunals or National Tribunals that have been established for that purpose and are binding upon the parties unless vetoed or modified by the relevant state or Federal government. From the available, if dated evidence, it appears as though settlements through adjudication rather than collective bargaining have been the most pervasive form of interest based settlement (Sodhi and Plowman, 2001, p.59) ). Recognised unions are given statutory rights to represent workers in any disputes which come before a conciliation officer, board, labour court or tribunal that is established under the Act.

In addition to specifying a host of unfair labour practices, the Industrial Disputes Act is immediately relevant to two other areas of employment relations. First, it provides detailed rules with respect to employer initiated changes (such as layoffs and retrenchments), which 
first must receive approval from the appropriate court or tribunal and second, it criminalises certain categories of industrial action. With respect to the former, in establishments of 100 or more employees who have at least one year of service, workers are entitled to half their normal pay for a period of 45 days in the event of a layoff being approved. One month's notice must be provided for any retrenchments and workers are again entitled to 15 days of their normal pay for each year of service. The same provision also applies to permanent closures, except here, the employer is required to provide 60 days advance notification. Any other changes in the terms or conditions of employment must be preceded by a 21 day notification.

On the union's side, notice of strike action must be provided to employers two weeks before such action is taken, while strikes and lockouts are outlawed during, and seven days after, any conciliation hearings or for the two months following any Labour Court or Tribunal hearings. Additionally, strikes are not permitted during the term of any conciliation award, which may be for a period of up to three years. Existing strikes can also be prohibited once reference has been made to the Act, with fines and jail terms imposed upon transgressors. All provisions in the Act cover establishments and industries that have been declared a public service, but the definition of such, contained in Schedule One of the Act, is very elastic. Governments can rule that just about any activity is temporarily a public service, including manufacturing and financial pursuits in the private sector. Thus, governments may choose to include or to exclude various activities from the provisions of the Disputes Act as they see fit.

The laws regulating strike and lockout activity seem to be 'honoured in the breach'. By no stretch of the imagination has such activity ceased to occur in Indian employment relations. The numbers of recorded strikes has declined dramatically since the early 1980s, falling by more than 80 percent, although strikes and lockouts have become larger in the sense of involving many more workers. Overall, the number of person days lost on account of disputes has declined somewhat since 1981, but nowhere near as dramatically as the actual number of disputes (India Labour Bureau, 2004). It would be incorrect to attribute any of these trends to statutes that have been on the books for over 50 years. Rather, the foreign exchange crisis of 1990-91, the turn towards the IMF and the subsequent adoption of neo-liberal remedies, as elsewhere, had a chilling effect on employment security, which made its effects known in the number of recorded industrial disputes.

Overall, and given the ambit of the Industrial Disputes Act, it can be seen that it is weighted in terms of the status quo (Chibber, 2003). Proposed changes for shutdowns, labour force reductions, or other significant alterations can quickly be removed from the realm of managerial prerogative and become the subject of an award. The whole tenor of the Indian system is control through protection, a logic that is largely at odds with the market rationality of globalisation. And although this is frequently an object of complaint, in truth requirements such as those contained in the Industrial Disputes Act, have had little impact on the IT/ITES/BPO sector. There are several reasons for this.

First, existing legislation was mainly intended to apply to and protect low wage manual workers. Those earning more than 1,600R per month (\$US 35) and/or exercising supervisory, administrative or managerial tasks are exempt from the Industrial Disputes legislation. This would include most of the IT/ITES/BPO sector, where for example, average starting salaries in call centres are many times that amount. In other words, salaries in ITES are at a level which exempts workers in the sector from essential features of the system, but still renders them hugely inexpensive by western standards. Second, to date, the main issue for Indian 
IT/ITES/BPO providers has been recruiting and retaining labour, not shedding it, (see next section).

Given this mix of conditions, or what might be best described as a highly unstable 'equilibrium', it is still the case that despite reports of spontaneous job actions at individual call centres, the IT/ITES/BPO sector remains completely union free. To understand why this is the case, and to appreciate the challenges that union organising in the IT/ITES/BPO sector face, it is necessary to revert back to the IR context once again.

As part of this legacy, trade unions have been described as a "frail but enduring part of India's labour relations" (Ratnam, 2001). As we have seen, statutes governing unions have been permissive of the creation of very small entities. As a result, only 2 percent of registered unions have a membership exceeding 5000, while 40 percent have less than 100 members (Sodhi and Ploughman, 2001, p.140-156). Historically, this has gone along with excessive fragmentation. Thus, there are no less than a dozen central labour organizations operating in India, each with its own political affiliations, to which only 20 percent of registered unions are affiliated (Ratnam, 2001). As a result, specific enterprise unions also proliferate. Multiple plant/office unionism has added immensely to the complexity and divisiveness of the situation. It has resulted in a situation described by one analyst where "the arduous task of organizing a trade union from scratch has suddenly lost is relevance: the easier path to ascendance as a leader is to take over existing organizations.” (Ramaswamy, 1988). This has gone along with an intense politicization that has left unions beholden to specific political parties, as well as dependent upon state patronage and reliant upon professional outside leaders (Chibber, 2005). None of these traits are favourable to an organising model (Bronfenbrenner, Friedman, Hurd, Oswald and Seeber, 1998) of union growth into information and knowledge based industries. As result, overall union densities in India are estimated to be about one-third of the organized sector of the economy or about 1 percent of the total societal labour force (Ratnam, 2001, p.32).

On top of the historical legacy and peculiarities of trade unionism in India, more recently, various state governments have announced several special promotional schemes that encompass a comprehensive package of incentives and policies for the IT/ITES/BPO industries and further add to the uniqueness that is encountered in this sector. Most of the states in India have Software Technology Parks (STPs) and Export Processing Zones (EPZs) that offer first world infrastructure within the STP gates. With respect to changes in existing labour codes, a majority of the states have either promulgated a government order or notification permitting all establishments in the respective jurisdictions engaged in ITenabled services (including call centres) to: work on national holidays; allow women to work through night shifts; and permit offices to function 24 hours a day, all through the year (Nasscom-g, 2005), although such practices have traditionally been banned through urban Shops and Establishment Acts (Confederation of Indian Industry, 2004).

For example, the 2003 IT and ITES Policy (Nasscom-h, 2005) of the state of Maharashtra (of which Mumbai, the commercial hub of the country, is the capital) and which accounts for $20 \%$ of the country's exports, aims to "create hassle-free and industry friendly, $24 \times 7 \times 365$ working environment" for the sector by amongst other things:

o Relaxing working hours, work shifts and employment of women under Shops and Establishments Act,

o Applying all relaxations under the Industrial Disputes Act and Contract Labour Act to all IT and ITES units in the state on par with Special Economic Zones, 
o Notifying IT \& ITES units as continuous process units

o Issuing special passes to vehicles transporting women workers of IT \& ITES units during night times,

o Declaring IT \& ITES units as public utility services and essential services (Nasscom-h, 2005).

Similarly, the state of Andhra Pradesh's “AP Policy on Information Technology Enabled Services” dated $29^{\text {th }}$ January, 2002 also commits to providing a supportive environment by amending the AP Shops and Establishments Act to allow ITES companies to:

o Employ women and young persons (between the age group 18-21) during night shifts, subject to provision of adequate security and transport

o Have "flex-timing" by asking an employee to work for more than 8 hours a day, without exerting an additional financial burden on the companies, in terms of overtime payments, as long as the statutory requirement on the maximum weekly working hours of 48 hours is respected

o Operate 24 hours a day and 365 days in the year, and

o Reduce the procedure involved in retrenching employees, if certain conditions are satisfied (Nasscom-i, 2005).

Currently, the IT/ITeS sector is devoid of the presence of trade unions. Existing unions appear to be unprepared to enter the new economy, but there is also a growing sense, as one manager put it "it's not a question of if, but of when" a trade union presence will develop. Considering the massive increase in employment in the ITeS industry and work environments characterised by round the clock work shifts, monotony, burnout and performance based employment, the question of whether trade unions will enter this new age industry raises heated discussion amongst politicians, trade unionists, industry analysts and employers. The employers' view is that there is no need for an external entity to represent employee voice because the IT/ITeS sector needs more people than it can get due to its phenomenal growth rate. This fact is said to promote best practices in people management and according to Bhargava, the former CEO of Progeon, "there is more that is good here than it has ever been in any single economic sector of India”. Attrition rates in the industry, however, testify to alternative realities. More than likely, should the manager's prognosis cited above come to pass it will be at individual worksites, generated by specific grievances, and will assume the form of enterprise unionism. In the meantime, internal employment relations are largely regulated through HR practices, which are described in the next section.

\section{HR Issues \& Challenges}

For an industry that is labour intensive and one that has experienced phenomenal growth in a short period of time, the implications for human resource management (HRM) of Indian ITES/BPO are enormous. Based on our research and secondary data, we conclude that the Indian IT/ITeS industry faces five important HR issues and challenges, namely, acute skill shortages, attrition, a leadership vacuum at the team level, escalating labour costs and a squeeze in profit margins. These are discussed in detail below.

\section{Skill Shortages}

Offset against the huge pools of surplus labour that define the Indian economy in general, are the employability demands of the BPO sector. Each component of the sector requires tertiary level education in a society where literacy rates hover around 65 percent for the population as a whole and at $45 \%$ for females. Jobs in IT minimally require a tertiary degree in engineering, 
computer science or mathematics, while call centre and data processing operations insist upon a Bachelors' level degree and high levels of proficiency in spoken and written English. Paradoxical as it may seem, it is currently a sellers market for labour in this particular enclave economy. It is estimated that by 2012, the labour power requirements for the off-shore Indian IT/ITeS markets, as well as domestic and captive IT/ITeS support requirements, will add up to 4-6 million workers (KPMG, 2004). While India could be one of the few countries with a qualified surplus labour pool by 2020, there is a possibility of a shortage in terms of skilled personnel for IT/ITeS to the tune of about half million workers, even in the medium term, that is, by 2009. (KPMG, 2004: 19 \& Taskforce, 2003: 6).

The employable labour shortage is already impacting on the performance of the Indian IT/ITeS industry today in terms of attrition levels and wage trends (see below). The question here is of quality, not quantity. While it is estimated that approximately 17 million people will be available to the IT industry by 2008 (Nasscom-j, 2005), the problem relates to their employability and trainability. "The issue of manpower gap is not as much about institutional seat availability as about the nature of skills and training provided in these institutions”. (Taskforce, 2003: 6).

According to one report, "Different categories of work at the agent level ... will require specific qualifications. These must be supported by some necessary delivery-related skills, such as language skills, analytical skills, computer proficiency, customer service orientation and behavioural traits" (KPMG, 2004: 34-36): While these are common requirements for CSRs anywhere in the world, in the context of India, staff need to be equipped with additional skills, such as language neutralisation, cross-cultural skills and familiarity with products that are not commonly used in India, such as credit cards. For high-end R\&D work, Indian employers are constrained by the low base of available PhDs, the low enthusiasm of higher educated staff for R\&D activities and the low growth in R\&D staff (KPMG, 2004: 53; Saini and Budhwar, 2004).

To address the manpower requirements, the Ministry of Communications and Information Technology's Taskforce on meeting the HR Challenges in IT and ITES (2003: 12) recommends addressing the entire development lifecycle of human resources, from attracting the right people through to education, certification, deployment and retraining. This requires close cooperation and coordination between governments, education institutions, industry bodies and individual firms. NASSCOM, the industry body, has already moved to establish a common certification system for some of the standard skills. For example, it recently launched the NASSCOM Assessment of Competence (NAC) for potential employees in the BPO industry as an industry standard assessment program with the aim of ensuring the transformation of a 'trainable' workforce into an 'employable' workforce (The Hindu, 2005b). Some states, such as Karnataka and Andhra Pradesh, have already moved to establish centralised testing and certification for potential employees in the industry (KPMG, 2004: 6566). However, the breadth and depth of skills and competencies required for the industry are of such a nature that the scope for effective standardisation of skill testing and training will be quite limited. Therefore, KPMG (2004: 63) recommends a hybrid model with base-level common testing and certification supported by company-specific programs.

One of the leading BPO firms that we studied is engaged in educating the public and local colleges in enhancing the employment reputation of ITES work, tarnished by the social stigma of working unsocial hours and allegations of sweatshop like conditions. Other companies also following suit with open-days for the parents of young staff to see first hand 
what the ITES industry is all about. To spread employment networks beyond tier one cities, such as Bangalore, Delhi and Hyderabad, the ITeS companies are also moving to set up facilities in tier two cities as well. Additionally, some Indian ITeS companies have started attracting "non-employed" people, such as retiring army personnel, teachers and housewives (KPMG, 2004: 73)

\section{Attrition}

This currently seems to be the biggest challenge currently facing the ITES/BPO sector. The 'race for talent' as one HR manager described it between BPO suppliers is fierce, and with turnover rates that are cited to be between 90 and 120 percent per annum in the ITES sector (Datamonitor, 2005 and interviews), the poaching of workers has created much distrust among industry participants. Typical of these dynamics, is one firm of 2600 CSRs where the authors carried out field work. Just to keep the workforce on an even keel, 300 agents per month need to be recruited, while half of the centre's 100 percent quit rate occurs within the first three months of an agent commencing work. These figures mirror overall ITeS/BPO corporate experience where, particularly in voice based call centres, the average tenure of CSRs is less than 12 months. Of the four ITeS companies that the authors have first hand experience with, employee attrition was hovering at above $100 \%$ except in one where it was said to be $45 \%$, possibly because the bulk of its operations are non-voice. Absenteeism ranges from $2-8 \%$ on a daily basis (Business Line, 2004). Some companies try to artificially bring down the attrition figures by excluding those who leave during the training/induction period or by omitting involuntary turnover, such as dismissals due to poor performance.

The reasons for attrition are manifold. One survey identified the following top five reasons for turnover in the industry: dissatisfaction with salaries (47\%), lack of career opportunities (45\%), leaving to pursue higher education (29\%), illness (28\%) and physical strain (22\%) (DQ-IDC, 2004). The average working day in the organised sector of the economy, including ITES/BPO is nine hours, which includes an hour of break time, or over an hour per day longer than is typical of economies such as Australia's. To this can be added lengthy commuting times in company supplied vehicles to and from work on clogged infrastructure. However, according to the survey, the average employee satisfaction score remained high at $80.7 \%$ with bigger companies achieving higher satisfaction ratings. As jobs are not being seen as careers, significant numbers of people leave to pursue higher education (Datamonitor, 2005).

In the interviews that the authors conducted with the HR managers, marriage and pursuing higher education were frequently quoted as the main reasons for attrition. The night shift work that most of the employees are engaged in causes them, particularly, women, to leave this employment when they get married; hence, marriage is given as the reason for attrition. In addressing the issue of employees leaving to pursue higher education and greener pastures, some companies are beginning to explore the possibility of providing scholarships, tuition reimbursement and special arrangements with education institutions that would allow them to offer courses in the workplace - thereby enabling employees to pursue higher education. However, part-time employment and flexi-hours are rarely practiced. Internal promotion is another measure frequently taken to address attrition but its scope is limited. In companies that do undertake both IT work and ITES there is little movement from the latter to the more highly skilled work of IT support and development. Within the ITES sector there is little sense of opportunity for significant career development. Performance bonuses, which are very popular in Indian call centres, are also used to prevent job-hopping but the intense 'race for talent' temporizes the effects of such schemes. Most big companies provide various 
facilities, such as transport and subsidised meals and conduct frequent 'town-hall meetings' to ascertain and address grievances.

\section{Escalating Wage Costs}

Rising wage costs are an increasing worry for the industry and its peak organisation Nasscom. Although salaries are high by the standards set by the Industrial Disputes Act and regional minimum wage rates, there is still pressure to increase them further as occurred between 2000 and 2003 when salary costs increased from USD 200/ month to USD $330 /$ month. As a result of this, company operating profit margins decreased from $30-40 \%$ to $17-25 \%$. This has made the industry as a whole in India less competitive on a global scale and less attractive for potential entrants (KPMG, 2004: 29).

An escalating wage bill is driven by a variety of factors including: fierce competition for skilled personnel, particularly for those with a year or more of experience; the increased emphasis on performance bonuses; and poaching via hefty salary increases especially on the part of the multinationals. Anecdotal evidence suggests that between 1995 and 1999, Indian software salaries increased by $45 \%$, whereas in the USA, the increase was only $21 \%$ (Mittal and Goel, 2004). In 2005, India had the best average pay increase in the whole of Asia at $14.1 \%$ as against China at $8.1 \%$. The pay hikes in the Indian IT and ITeS industry were even higher at $16 \%$ and $15.4 \%$, respectively (Sify, 2006). The performance based variable pay in one IT company varies from 30-50\% at higher levels and 7-15\% at lower levels (Saha and Chatterjee, 2004). Add to this employee transport costs funded by the employer, which are peculiar to India due to the poor transportation infrastructure. One company where the authors undertook field work logged 60,000 kms per day in providing transportation to ferry the workforce between home and the office! Food vouchers, which are supplied for company canteens, are also a standard 'benefit' and they account for another $15 \%$ or so of total employee costs, according to the managers who were interviewed for this study. This is further compounded by the ever recurrent recruitment costs arising out of high attrition rates and training periods which may be prolonged through having to include extra modules in language and culture.

Thus, one can see the cost advantage of the IT/ITeS sector being eroded. However, according to some analysts, "as long as productivity and the value of work done are high", this should not pose a serious problem in the short to medium term (Mukherjee, 2005). Clearly, with basic wage costs (wages minus associated costs such as transportation and bonuses) in ITES being only about $10 \%$ of Australian wages there is still room for manoeuvre. Indeed, the model of employment we have been describing is mainly sustainable in the context of very low basic wages.

\section{A Profit Squeeze}

Clients on multi-year contracts with BPO providers expect costs to fall over the course of the tender as the provider becomes more experienced and familiar with the client's products and markets. These expectations are forwarded on to the supplier with multi-year contracts that reflect the expectation of declining costs being shared with the client. However, given the levels of turnover in the industry, and the associated costs of recruitment, training and wage/benefit competition, diminishing unit costs over time are anything but a foregone conclusion. Instead, training costs are more likely to remain constant, while both wage bills and associated costs such as workforce transportation are under pressure to rise, especially with rapidly escalating energy costs. BPOs can quickly find themselves being squeezed, while this pressure is passed on to the workforce in terms of work expectations and 
heightened levels of work intensity, which feed back into the attrition and related problems that we have already discussed. In this manner, what was a 'virtuous circuit' for the industry may be on the verge of turning into something quite different.

\section{Supervisory Skill Vacuum}

Leadership and supervisory skills shortages, particularly at the team/project level are another challenge to the IT/ITeS sector (Agrawal and Thite, 2006 and 2003). It is estimated that it takes about five years for a call centre market to establish its own middle management capabilities and India is still a couple of years behind before "all parts of the market are sufficiently staffed from within” (Datamonitor, 2005). NASSCOM, the industry's apex body, has moved to address this issue by instituting a "Certification Program for Building Frontline Managers” for quality analysts and team leaders (Nasscom-k, 2005).

\section{Conclusion}

In the $21^{\text {st }}$ century, the world of work is changing rapidly both in manufacturing and services. In the last century, most of the blue and white-collar work was conducted in developed economies and in-house. Just as falling transportation costs have enabled the globalisation process to separate the geography of industrial production and consumption with countries, such as China, emerging as new manufacturing leaders, the spread of the internet, with cheap and abundant telecommunications bandwidth, has enabled businesses to outsource whitecollar work to specialist outside suppliers, with countries, such as India emerging as important hubs for producing services for consumption at the other end of the fibre-optic cable (Edwards, 2004).

Apart from its sheer size, India currently constitutes an intriguing part of the globalization story for its pioneering of what can be termed an Export Led Services Provision (ELSP) model. Today, anybody who visits India will see that changes are everywhere and the country is well and truly on the move. It still remains a country of complete contrasts - five star hotels surrounded by slums, white collar workers rushing past unskilled labourers using primitive technologies, new globally branded cars navigating congested roads along with antiquated models, free ways and flyovers that suddenly lead to unpaved, snarled roads and so on.

Optimists such as Akshaya Bhargava, the former CEO of Progeon (the ITES arm of the globally reputed Indian IT multinational, Infosys), argue that what the IT industry did to India during the 1990s is akin to an "underwater earthquake" (The Business Standard, 2004). He asks a pointed question, "if half a million people (employed by the IT industry) can transform India in 10 years, imagine what 12 million (expected to be employed by the IT/ITeS sector by 2014) can do"? According to him, this invisible, but real rising tide, will create a tectonic social shift, improving the lot of what is soon to be the most populous nation on earth. Its imprint on the world is already unmistakable. Yet this begs larger questions.

Currently, the BPO sector appears poised on an unstable knife edge. It involves a young, highly educated workforce conducting often routine work for which, in many cases, it is patently over qualified. As a result, the explosive growth of BPO in India has also given rise to startling attrition rates and working conditions that, although perhaps (temporarily) acceptable in urban India may well prove to be far short of employee aspirations. 
Will India become the first successful case of Export Led Services Provision (ELSP) in the same way that the Asian Tigers have successfully pursued and brought to fruition a model of Export Led Industrialisation (ELI)? Or will the ELSP economy remain an enclave or 'island' economy as is currently the case? Can an ELSP model develop in the absence of political coordination and coherence, or without massive public investment in physical infrastructure, or will neo-liberal policies prove sufficient to launch a new era of socio-economic development on the sub-continent? Despite the spectacular growth and visibility of the IT/ITES sector, it is still largely irrelevant to the vast majority of Indians. Still, there is no mistaking the changes that IT/ITES/BPO have brought. While the Indian economic elephant is certainly stirring and moving, only time will tell whether its insertion into the global knowledge economy will bring with it societal standards befitting the $21^{\text {st }}$ century, or new forms of economic dependence.

\section{References}

Agrawal, N. M. \& Thite, M. 2006. 'Nature \& importance of soft skills in software project leaders’. Asia Pacific Management Review, 11(2), 405-413.

Agrawal, N. M. \& Thite, M. 2003. 'HR issues, challenges \& strategies in Indian software services industry’. Intl. Journal of Human Resources Development and Management, 3(3), pp. 249-264.

Bronfenbrenner, K., Friedman, S., Hurd, R., Oswald, R., and Seeber, R. 1998. Organizing to Win: New Research on Union Strategies. Ithaca: Cornell University Press.

Business Line. 2004. 'Attrition, absenteeism bug BPO cos'. April $22^{\text {nd }}$.

Census of India 2001. www.censusindia.net. T 00-009: Distribution of workers by category of workers.

Chandler, C. 2005. 'India on the move’. Fortune. October 31, 2005.

Chibber, V. 2003. Locked in Place: State-Building and Late Industrialization in India. Princeton: Princeton University Press.

Chibber, V. 2005. 'From Class Compromise to Class Accommodation: Labor's Incorporation into the Indian Political Economy' in Ray, R. and Katzenstein, M. (eds), Social Movements In India: Poverty, Power and Politics. Lanham MD: Rowman and Littlefield.

Confederation of Indian Industry, Northern Region. 2004. 'Driving Growth Through Reform: A comparative Analysis of Labour Practices in Select Northern Region States'.

Datamonitor. 2005. The future of contact centre outsourcing in India and the Philippines. February, 2005.

Director General of Employment and Training (various years). Employment Review. Delhi: Government of India

DQ-IDC. 2004. 'India BPO Employee Satisfaction Survey' http://www.bpo.nasscom.org/artdisplay.aspx?art_id=3709\&cat_id=609 downloaded $9^{\text {th }}$

December, 2005 
Economist, 2006. http://www.economist.com/countries/india/profile.cfm?folder=ProfileFactSheet

Economist. 2005. http://www.economist.com/countries/India/index.cfm

Edwards, B. 2004. 'A world of work’. The Economist. November 11, 2004.

Florida, R. 2002. The Rise of the Creative Class: and how it's transforming work, leisure, community and everyday life. New York: Basic Books.

Friedman, T. L. 2005. 'The world is flat: A brief history of the twenty-first century'. New York: Farrar, Straus \& Girou.

Gupta, A. and Kumarkaushalam.. 2005. 'The Changing Face of Indian Exports', Business Today, November, $6^{\text {th }}$.

India, Labour Bureau (2004) Indian Labour Yearbook. Delhi: Ministry of Labour, Government of India.

Jones, C. 2005 ‘ANZ jobs head to India’, The Courier Mail, November, $29^{\text {th }}$.

KPMG. 2004. 'Strengthening the human resource foundation of the Indian IT enabled services industry’. Report by KPMG Advisory Services Private Limited in association with NASSCOM under the aegis of the Department of IT, Ministry of Information Technology and Communications, Government of India.

Kripalani, M. and Engardio, P. 2005. 'The rise of India'. BusinessWeekOnline. http://www.businessweek.com/magazine/content/03_49/b3861001_mz001.htm downloaded on 9th May, 2006.

Krishnamurthi, S. 2002 Commercial's Commentary on Trade Unions Act, 1926 As Amended by Trade Unions (Amendment) Act 2001. Delhi: Commercial Law Publishers.

Mittal, A. \& Goel, S. 2004. 'Globalization and Indian IT industry: A strategic perspective'. In Information technology: Issues and challenges of globalisation. New Delhi: Indian Institute of Foreign Trade.

Mukherjee, A. 2005. 'India’s software dream run is far from over'. Bloomberg. June $10^{\text {th }}$ 2005

Nasscom-a. 2005. http://www.nasscom.org/strategic2005.asp downloaded on 9th May, 2006.

Nasscom-b. 2005. http://www.nasscom.org/articleprint.asp?art_id=4163 downloaded on $27^{\text {th }}$ November, 2005. 
Nasscom-c. 2005. http://www.nasscom.org/articleprint.asp?art id=4413 downloaded on $29^{\text {th }}$ November, 2005.

Nasscom-d. 2005. http://www.nasscom.org/articleprint.asp?art_id=4154 downloaded on $27^{\text {th }}$ November, 2005.

Nasscom-e. 2005. http://www.nasscom.org/articleprint.asp?art_id=4400 downloaded on $29^{\text {th }}$ November, 2005.

Nasscom-f. 2005. http://www.bpo.nasscom.org/artdisplay.aspx?cat_id=588 downloaded on $29^{\text {th }}$ November, 2005.

Nasscom-g. 2005. (http://www.bpo.nasscom.org/artdisplay.aspx?cat_id=563 downloaded on $27^{\text {th }}$ November 2005)

Nasscom-h. 2005. (http://www.bpo.nasscom.org/download/Maharashtra\%20ITeSPolicy2003.pdf downloaded $23^{\text {rd }}$ December.

Nasscom-i. 2005. (http://www.bpo.nasscom.org/download/AP\%20ITES\%20Policy.pdf downloaded on 23 $3^{\text {rd }}$ December.

Nasscom-j. 2005. http://www.nasscom.org/articleprint.asp?art_id=4728 downloaded on $29^{\text {th }}$ November, 2005

Nasscom-k: 2005. http://www.nasscom.org/artdisplay.aspx?cat_id=869 downloaded on $29^{\text {th }}$ November, 2005

Ramaswamy, E.A. 1988. Worker Consciousness and Trade Union Response. New Delhi: Oxford University Press.

Ratnam, V. 2001. Globalization and Labour-Management Relations: Dynamics of Change. New Delhi, Sage.

Reich, R. B. 1991. The work of nations: Preparing ourselves for $21^{\text {st }}$ century capitalism. New York: A.A.Knopf.

Saha, A. \& Chatterjee, S. 2004. 'Human resource and cultural dynamics of global IT companies'. In Information technology: Issues and challenges of globalisation. New Delhi: Indian Institute of Foreign Trade.

Saini, D. and Budhwar, P. (2004) 'HRM in India', in Budhwar, P. (ed), Managing Human Resources in Asia-Pacific. London: Routledge.

Sheshabalaya, A. 2005 Rising Elephant: The Growing Clash with India over White-Collar Jobs and its Challenge to American and the World. Delhi: Macmillan.

Sify. 2006. 'India Inc gave heftiest pay hikes in Asia'.

http://headlines.sify.com/news/fullstory.php?id=14136242 downloaded $3^{\text {rd }}$ May, 2006 
Sodhi, J.S. and Plowman, D. 2001 Economic Change and Industrial Relations: India and Australia. Nedlands WA: Scholastic Press Australia.

Taskforce. 2003. 'Taskforce on meeting the human resources challenge for IT \& IT enabled services'. Government of India, Ministry of Communications and Information Technology. Department of Information Technology. $18^{\text {th }}$ December 2003.

The Business Standard. 2004. 'Akshaya Bhargava: The underwater earthquake’. July $23^{\text {rd }}$, 2004. http://www.nasscom.org/artdisplay.asp?Art id=3015 downloaded $9^{\text {th }}$ May, 2006.

The Hindu. 2005a. Knowledge services: Leveraging Indian talent. The Hindu Survey of Indian Industry 2005. Chennai: The Hindu.

The Hindu. 2005b. 'NASSCOM programme for future BPO workers'. October, $14^{\text {th }}$. 